\title{
Metasomatized Kyanite-eclogites xenoliths from a southern Indian kimberlite
}

\author{
K. C. Misra ${ }^{1}$, M. Anand ${ }^{2,3}$, D. K. Paul ${ }^{4}$ \\ ${ }^{1}$ Department of Earth \& Planetary Sciences, University of Tennessee, Knoxville-37996, Tennessee, U.S.A. \\ ${ }^{2}$ Department of Earth and Environmental Sciences, The Open University, Milton Keynes, MK7 6AA, U.K. \\ ${ }^{3}$ Department of Mineralogy, The Natural History Museum, Cromwell Road, London, SW7 5BD, U.K. \\ ${ }^{4}$ Department of Geology, Presidency College, Kolkota, 700073, India
}

\section{Geologic setting}

Kimberlites discovered so far in southern India are restricted to the Eastern Block of the Dharwar Craton and are distributed in three fields: Wajrakarur, Narayanpet, and Raipur. As summarized recently by Paul et al. (2006) and Patel et al. (2006), known kimberlite pipes in the Wajrakarur kimberlite field (WKF), which lies at the western margin of the Cuddapah Basin, occur in three clusters: Wajrakarur Lattavaram (13 pipes, P-1 to P-13); Chigicherla (5 pipes, CC-1 to CC-5); and Kalyandurg (4 pipes, KL-1 to KL-4).

The xenoliths we have studied are kyanite-bearing eclogites, and they all come from surface exposures of the KL-2 kimberlite in which the xenolith population is dominated by eclogites (Rao et al., 2001). The Kalyandurg pipes intrude outliers of the 2.6-2.5 Ga old Closepet Granite (Neelakantam, 2001), and appear to be localized close to major ENE-WSW trending faults and their intersections with NW-SE faults/fractures (Nayak et al., 2001). None of the pipes in the Kalyandurg cluster has been dated, but many of the pipes in the Wajrakarur cluster have yielded phlogopite $\mathrm{Rb}$-Sr ages of $1019 \pm 20$ to $1093 \pm 20 \mathrm{Ma}$ (Anil Kumar et al., 1993) and whole-rock K-Ar ages of $840 \pm 33$ to $1023 \pm 40 \mathrm{Ma}$ (Paul et al., 1975). Most of the pipes in the WKF are diamondiferous, but no diamond was found in any of the 15 xenoliths in our collection.

\section{Petrography}

The essential primary mineralogy of the kyanitebearing eclogites consists of omphacite (Cpx1; > 4.5 wt $\% \mathrm{Na}_{2} \mathrm{O}$ ), occasionally as stubby crystals with triple junctions, garnet, which typically occurs as subhedral crystals surrounding omphacite (the so-called "necklace texture"), and euhedral crystals of kyanite that contain small inclusions of garnet and clinopyroxene. Some of the xenoliths also contain a few crystals of rutile, containing ilmenite lamellae, and trace amounts of fine-grained sulphides (bornite pentlandite, millerite, chaclocite, and some unidentified $\mathrm{Cu}-\mathrm{Ni}-\mathrm{Fe}$ phases). Some of the samples exhibit crude centimetre-scale banding between garnet-rich and garnet-poor compositions. The composition of garnet in any particular sample is fairly uniform, without any systematic zoning, but varies significantly among different xenoliths (Fig. 1). The reason for the apparent anomalous nature of KL 2-17 is yet to be resolved. In terms of garnet composition, the Kalyandurg eclogites are mostly Group B eclogites (Fig. 2).

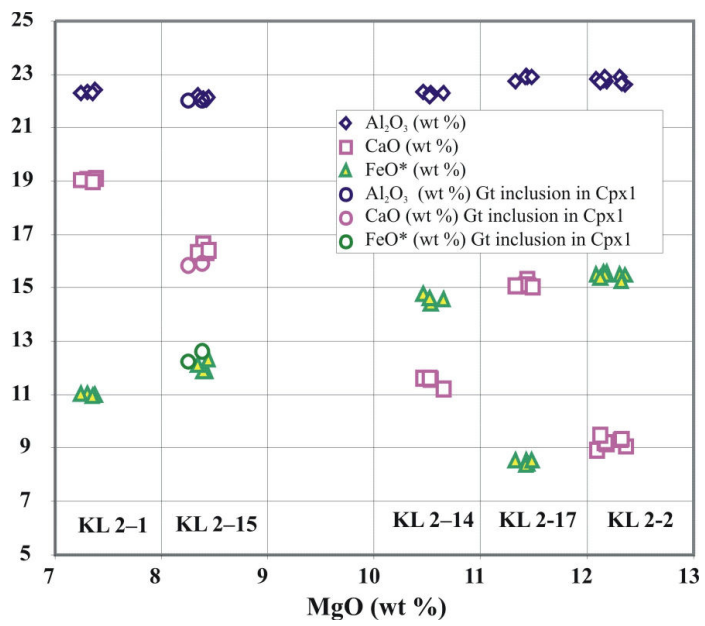

Fig. 1: Major-element oxide composition (all in wt $\%)$ of garnets in kyanite eclogite xenoliths from Kalyandurg kimberlite pipe KL-2. FeO* is total Fe.

Compared to garnet, which is relatively unaltered except for alteration rims and anastomosing veins of micaceous material, the omphacite is highly altered, with the original Cpx 1 surviving only as a few tiny islands. The intense alteration of clinopyroxene, a characteristic feature of kyanite-bearing eclogites, is believed to be due to M-site cation vacancy in the pyroxene that makes it highly unstable at lower pressures (Smyth, 1980). The alteration has produced Na-depleted clinopyroxene $\left(\mathrm{Cpx} 2 ;<4 \mathrm{wt} \% \mathrm{Na}_{2} \mathrm{O}\right)$ of highly variable composition (Fig. 3), along with a host of intergrown, fine-grained minerals (amphibole, zoisite, albite, K-feldspar (sanidine?), mica, chlorite, and some other phases yet to be identified). A 
conspicuous feature of $\mathrm{Cpx} 1$ alteration is its breakdown to form symplectitic intergrowth of $\mathrm{Cpx} 2$ and albite, most likely in response to a decrease in pressure during the ascent of the kimberlite magma. Some of the alteration mineralogy and textures may be the consequence of decompression partial melting during the ascent, but so far we have not identified any glass or devitrified glass in any of the xenoliths.

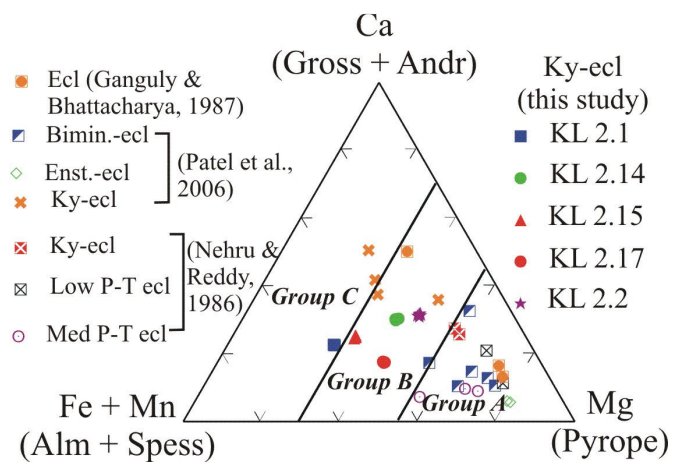

Fig. 2: Ternary ( $\mathrm{Fe}+\mathrm{Mn})-\mathrm{Mg}-\mathrm{Ca}$ compositions of garnets (in mole \%) in eclogite xenoliths (with or without kyanite) recovered from kimberlite pipes, southern India. The boundaries for the three groups of eclogites $(A, B$, and $C)$ are from Coleman et al. (1965).

Much of the kyanite is altered to prehnite, which is localized along cleavage planes; the most conspicuous product of kyanite alteration, however, is the occurrence of celsian (with or without strontium), which rims around kyanite as well as penetratively replaces kyanite. An accompanying abstract (Anand et al., this volume) discusses trace-element signatures of these eclogites. The present mineralogy and chemistry of the eclogites may be interpreted as a combination of mantle metasomatism and alteration in the upper crustal environment.

Our study also included a garnet pyroxenite xenolith from the same pipe but recovered from the borehole fluid. This xenolith is characterized by a bimineralic, xenoblastic assemblage of compositionally homogeneous garnet $(\mathrm{CaO}=4$ to $4.5 \mathrm{wt} \% ; \mathrm{MgO}=23$ to 24 wt \%) and diopside $\left(\mathrm{Na}_{2} \mathrm{O} \sim 1\right.$ wt \%). In sharp contrast to the eclogite xenoliths, the pyroxenite xenolith is remarkably fresh, suggesting that it was probably picked up by the kimberlite at a much shallower depth unaffected by mantle metasomatism.

\section{Geothermobarometry}

The geothermometer based on $\mathrm{Fe}-\mathrm{Mg}$ exchange between garnet $(\mathrm{Gt})$ and clinopyroxene $(\mathrm{Cpx})$ is commonly used for estimation of equilibration temperature in ultramafic xenoliths, but its application requires an independent estimation of pressure. In the absence of orthopyroxene or chromian clinopyroxene in the xenoliths, it was not possible to obtain an independent estimation of pressure. We have tried to estimate the P-T conditions of the eclogite xenoliths by
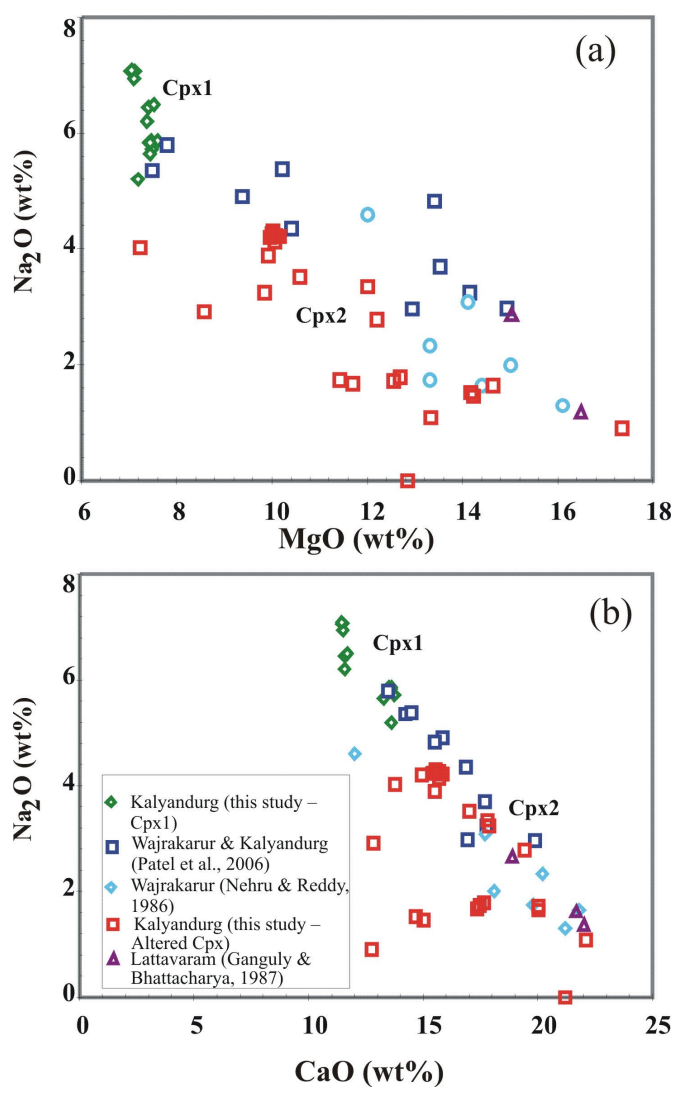

Fig. 3: Compositions (all in wt \%) of original omphacitic clinopyroxenes (Cpx1; > 4.5 wt \% $\left.\mathrm{Na}_{2} \mathrm{O}\right)$ and their Na-depleted alteration products $(\mathrm{Cpx} 2)$ in eclogite xenoliths recovered from the Wajrakarur kimberlite field (WKF), southern India: (a) $\mathrm{MgO}$ vs. $\mathrm{Na}_{2} \mathrm{O}$; and (b) $\mathrm{CaO}$ vs. $\mathrm{Na}_{2} \mathrm{O}$.

an indirect approach consisting of two steps. First, using the published data on temperature estimates of xenoliths recovered from the WKF and the compositions of their garnets and clinopyroxenes, we regressed the variation of the $\mathrm{Fe}-\mathrm{Mg}$ exchange distribution coefficient, which is defined as

$$
K_{D(\mathrm{Gt}-\mathrm{Cpx})}^{\mathrm{Fe}-\mathrm{Mg}}=(\mathrm{FeO} / \mathrm{MgO})_{\mathrm{Gt}} /(\mathrm{FeO} / \mathrm{MgO})_{\mathrm{Cpx}}
$$

as a function of temperature. We then used the regression line (Fig. 4a) to obtain temperatures corresponding to three eclogite samples for which we had the necesary compositional data. The second step was to construct a Proterozoic geotherm for the Eastern Dharwar Craton, using all the published P-T estimates for mantle xenoliths pertaining this craton (Fig. 4b). From this geotherm we estimated the pressures corresponding to the temperatures obtained in the previous step. The P-T estimates for the three eclogite xenoliths are as follows: 


$\begin{array}{lrr}\text { KL 2-2 } & 1052{ }^{\circ} \mathrm{C} & 42 \mathrm{kbar} \\ \text { KL 2-14 } & 1018{ }^{\circ} \mathrm{C} & 40 \mathrm{kbar} \\ \text { KL 2-15 } & 970{ }^{\circ} \mathrm{C} & 37 \text { kbar }\end{array}$
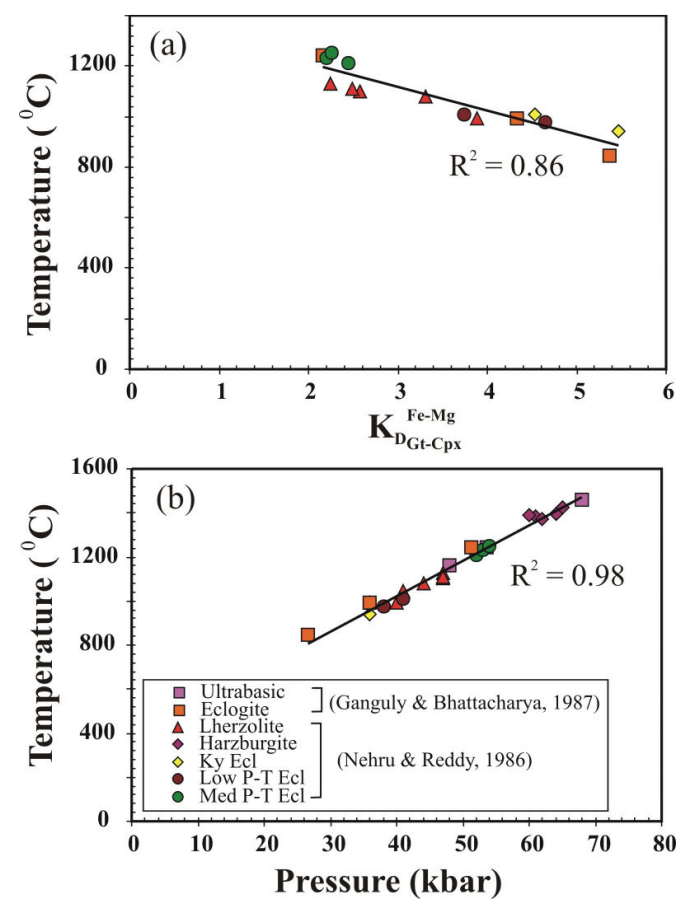

Fig. 4: (a) Distribution coefficient for $\mathrm{Fe}-\mathrm{Mg}$ exchange between garnet and clinopyroxene as a function of calculated temperature for mantle xenoliths in southern Indian kimberlites. (b) Estimated Proterozoic geotherm for the Eastern Dharwar Craton, southern India, based on the data from the sources listed in the legend.

These estimates are consistent with the lack of diamonds in the xenoliths but they do not preclude the prospect of the kimberlite being diamondiferous.

\section{References}

Anil Kumar, Padma Kumari, V.M., Dayal, A.M., Murthy, D.S.N., and Gopalan, K., $1993 . \quad \mathrm{Rb}-\mathrm{Sr}$ ages of Proterozoic kimberlites of India: evidence for contemporaneous emplacement. Precambrian Research $79,363-369$.

Coleman, R.G., Lee, D.E., Beatty, L.B., and Brannock, W., 1965. Eclogites and eclogites: their differences and similarities. Bulletin of Geological Society of America 76, 483-508.

Ganguly, J, and Bhattacharya, P.K., 1987. Xenoliths in Proterozoic kimberlites from southern India: petrology and geophysical implications. In Nixon, P.H., ed., Mantle Xenoliths, p. 249-265. New York: John Wiley.

Nayak, S.S., Rao, K.R.P., Kudari, S.A.D., and Ravi, S., 2001. Geology and tectonic setting of the kimberlites and lamproites of South India. Geological Survey of India Special Publication No. 58, 567-575.

Neelakantam, S., 2001. Exploration for diamond in southern India. Geological Survey of India Special Publication No. 58, 521-555.
Nehru, C.E., and Reddy, A.K., 1986. Ultramafic xenoliths from Vajrakarur kimberlites, India. In Kimberlites and Related Rocks, v. 2, Geological Society of Australia Special Publication No. 14, 745-758.

Patel, S.C., Ravi, S., Thakur, S.S., Rao, T.K., and Subbarao, K.V., 2006. Eclogite xenoliths from Wajrakarur kimberlites, southern India. Mineralogy and Petrology, $88,363-380$.

Paul, D.K., Rex, D.C., and Harris, P.G., 1975. Chemical characteristics and $\mathrm{K}-\mathrm{Ar}$ ages of Indian kimberlites. Geological Society of America Bulletin 86, 364-366.

Paul, D. K., Nayak, S.S., and Pant, N.C., 2006. Indian kimberlites and related rocks: petrology and geochemistry. Journal of the Geological Society of India 67, 328-355.

Rao, K.R.P., Rao, K.N., Dhakate, M.V., and Nayak, S.S. 2001. Petrology and mineralogy of Wajrakarur and Narayanpet kimberlite fields, Andhra Pradesh, India. Geological Survey of India Special Publication No. 58, $577-591$.

Smyth, J.R., 1980. Cation vacancies and crystal chemistry of breakdown reactions in kimberlitic omphacites. American Mineralogist 65, 1185-1191. 